\title{
Prospects for the use of sandwich panels in the construction industry of Kazakhstan
}

\author{
Zhumabek Omarov", Gulnara Zhukenova, Leonid Bulyga, and Murat Beisembaev
}

Toraighyrov University, 140000 Pavlodar, Kazakhstan

\begin{abstract}
One of the main priorities for the implementation of the tasks set in the Address of the Head of State Nursultan Nazarbayev to the people of Kazakhstan "Kazakhstan's way - 2050: common goal, common interests, common future" is the transition of traditional industries of Kazakhstan to the production of high value added products.

Structural insulated panel (SIP) in common people is a sandwich panel. Aside from the architectural and aesthetic requirements for building projects, sandwich panels could be called the ideal building material.

The shell of sandwich panels is made with a good and reliable anticorrosion coating, the insulation material has a low thermal conductivity, minimal moisture absorption, sufficient mechanical strength, and high durability. And the sandwich panel itself is resistant to harmful ultraviolet radiation, atmospheric and mechanical influences. In addition, any communications are easily laid through sandwich panels: drilling or cutting this structure is much easier than reinforced concrete panels.
\end{abstract}

\section{Introduction}

Sandwich panels have many performance benefits.

Firstly, in terms of their thermal characteristics, sandwich panels are superior to traditionally used building materials such as brick, wood, concrete, etc.

Secondly, the mass of sandwich panels is significantly less than that of traditional materials. This means that you can significantly reduce the load on the foundation, and in some cases do without it at all. In addition, transportation costs are significantly reduced, there is no need to transport heavy reinforced concrete panels or bricks.

Thirdly, sandwich panels are inexpensive and reliable structures, which allows you to save literally at every stage of construction, and not only money, but also time. For example, the fastening of a sandwich panel to the frame is done very quickly using self-tapping bolts for metal or wood, depending on what the frame is made of. By the way, that is why, if necessary, can dismantle the structure and move the building to another location.

Fourthly, sandwich panels do not require additional finishing. Their surfaces - thin sheet galvanized steel - are painted with reliable paint or covered with a polymer layer (Polyester, Pural, PVF-2, etc.) even in the factory.

\footnotetext{
* Corresponding author: zhumabek-omarov@mail.ru
} 
The advantages of sandwich panels include: the quality of the enclosing structures; good thermal insulation; excellent moisture resistance; lightness and strength; corrosion resistance; durability; convenient and inexpensive installation; wide range of colors; modern design.

High thermal insulation properties are the most important feature of modern sandwich panels. Compare: a sandwich panel with expanded polystyrene or mineral wool insulation with a thickness of $150 \mathrm{~mm}$ in terms of thermal insulation properties corresponds to a brick wall with a thickness of $900 \mathrm{~mm}$. Thanks to this, with the same thickness of a brick wall and a sandwich panel, heating costs are reduced several times.

Quality structural insulating products have certain technical and operational characteristics that should be considered. These include:

Thermal conductivity. For products with polyurethane insulation, it should be equal to $0.028 \mathrm{~W} /\left(\mathrm{m} \cdot{ }^{\circ} \mathrm{C}\right)$, with mineral wool $0.047-0.07$, with polystyrene $0.035-0.040$.

Indicator of adhesion of the heat insulator to the outer layers. It is equal to 1.2 and 1.5 $\mathrm{kgF} / \mathrm{cm}^{2}$ for wadded and expanded polystyrene insulation with a shift, 1.5 and 1.8 with a uniform separation.

Vapor permeability at the level of $0.05 \mathrm{mg} /(\mathrm{m} \cdot \mathrm{h} \cdot \mathrm{Pa})$.

SIP panels are often made according to individual sizes provided by the customer. In the construction of private houses, the construction of standard buildings, products with standard geometric parameters are used: thickness - 11-27 cm; length - 250-280 cm; width $-62.5-125 \mathrm{~cm}$.

SIP plates $17.4 \mathrm{~cm}$ thick with dimensions $62.5 \times 250$ are recommended for installation of roofs and intermediate floors. And panels with large geometric values $(125 \times 250)-$ for the construction of external walls.

\section{Experimental studies of the technical characteristics of sandwich panels}

For the purposes of scientific and experimental research at Toraighyrov University, tasks were set and the study of the possibility of using structural insulating SIP panels and an assessment of their advantages over other building materials and structures were set:

- study of the characteristics of structural insulating SIP panels;

- research of the technology of production of structural insulating SIP panels with the best insulation.

An overview of existing technical solutions for three-layer structures was also presented, their brief characteristics and examples of use were given, advantages and disadvantages were noted.

As the analysis of the main results of studies of three-layer structures has shown, the main attention was previously paid to the calculation of three-layer panels with insulation such as mineral wool and expanded polystyrene. In comparison, the polyurethane foam core in the panel structure has a pronounced orthotropic structure and its behavior in the panel is not well understood.

Structural insulating panels (SIP panels) were tested. The following indicators were tested: geometric parameters, strength under the influence of a uniformly distributed load, resistance to heat transfer, adhesion strength of components, physical and technical indicators of the insulation (density, compressive strength, tensile strength, moisture, thermal conductivity, water absorption, fire resistance). 


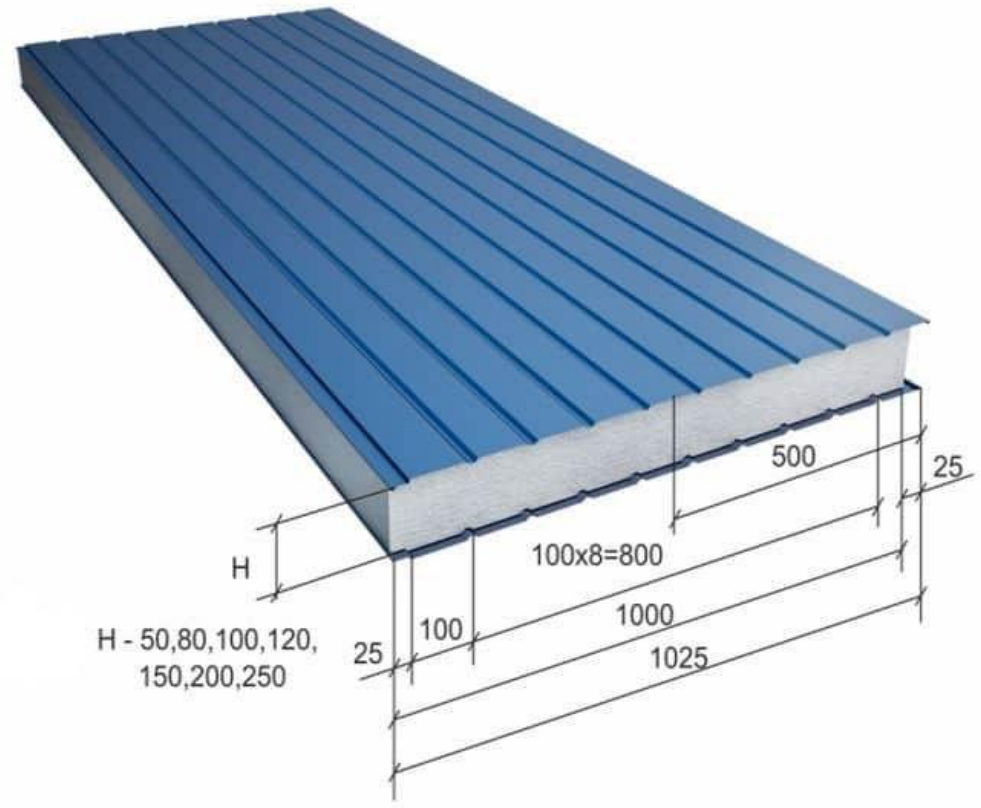

Fig. 1. Dimensions of wall sandwich panels

The panel length was measured along the central axis of the panel.

Strength under uniformly distributed load.

Special equipment determines the load at which deflection occurs in the core material, and the distance between the support points.

Tests are carried out on specimens in a four-point bend test.

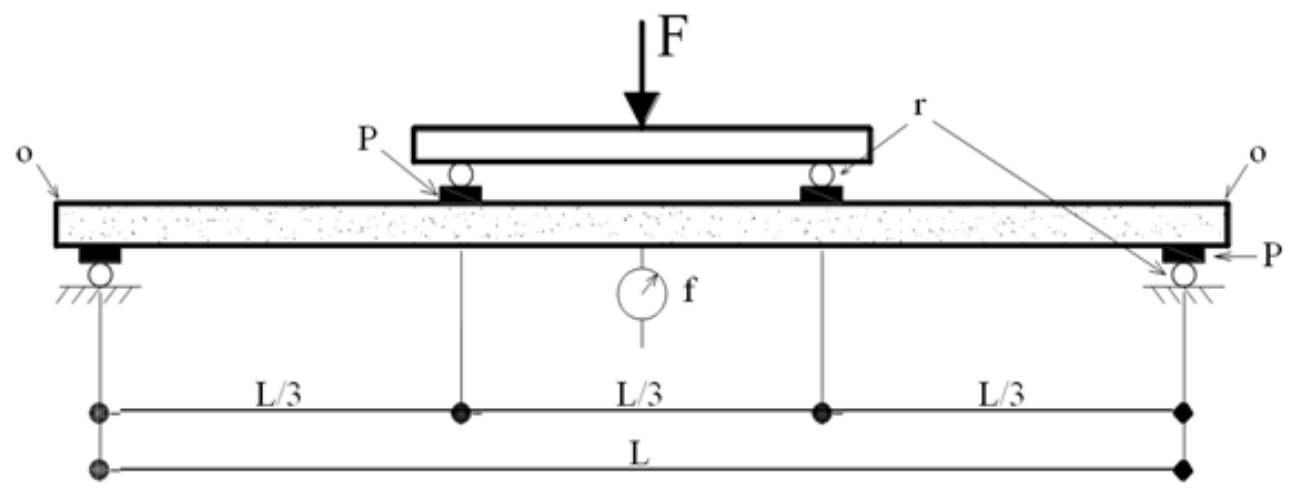

Fig. 2. Test scheme 
Table 1. Strength characteristics of sandwich panels

\begin{tabular}{|c|c|c|}
\hline \multirow{2}{*}{ Filler type } & Thickness, mm & $\begin{array}{c}\text { Breaking load at } \\
\text { transverse bending, } \mathbf{~ n o t ~} \\
\text { less, kgf }\end{array}$ \\
\hline \multirow{3}{*}{ Mineral wool } & 60 & 230 \\
\cline { 2 - 3 } & 100 & 300 \\
\cline { 2 - 3 } & 120 & 320 \\
\hline \multirow{2}{*}{ Expanded polystyrene foam } & 60 & 280 \\
\cline { 2 - 3 } & 100 & 430 \\
\cline { 2 - 3 } & 120 & 460 \\
\hline \multirow{3}{*}{ Extruded polystyrene foam } & 60 & 600 \\
\cline { 2 - 3 } & 100 & 690 \\
\cline { 2 - 3 } & 120 & 990 \\
\hline
\end{tabular}

Table 2. Comparison of extruded polystyrene foam and expanded polystyrene foam

\begin{tabular}{|c|c|c|c|c|c|c|c|}
\hline \multirow{2}{*}{ Characteristic } & $\begin{array}{c}\text { With a filler thickness } \\
\text { of extruded } \\
\text { polystyrene foam } \\
\text { (ST), mm }\end{array}$ & $\begin{array}{c}\text { With a filler } \\
\text { thickness of extruded } \\
\text { polystyrene foam } \\
\text { (ST), mm }\end{array}$ & $\begin{array}{c}\text { Test } \\
\text { method } \\
\text { s }\end{array}$ \\
\cline { 2 - 7 } & $\mathbf{8}$ & $\mathbf{2 2}$ & $\mathbf{3 0}$ & $\mathbf{8}$ & $\mathbf{2 2}$ & $\mathbf{3 0}$ & \\
\hline $\begin{array}{c}\text { Compressive strength at 10\% } \\
\text { linear deformation, MPa, not } \\
\text { less }\end{array}$ & 0,27 & 0,28 & 0,3 & 0,26 & 0,27 & 0,28 & GOST \\
& & & & & & & 15588 \\
\hline $\begin{array}{c}\text { Flexural strength, MPa, not } \\
\text { less }\end{array}$ & 0,96 & 0,97 & 0,98 & 0,94 & 0,95 & 0,96 & $\begin{array}{c}\text { GOST } \\
15588\end{array}$ \\
\hline
\end{tabular}

Table 3. Coefficients of resistance to heat transfer

\begin{tabular}{|c|c|c|}
\hline $\begin{array}{c}\text { Sandwich panels made of } \\
\text { various insulation materials }\end{array}$ & $\begin{array}{c}\text { Coefficients of thermal } \\
\text { conductivity, W/(m·K) } \\
{\left[\mathbf{k c a l} /\left(\mathbf{m} \cdot \mathbf{h} \cdot{ }^{\circ} \mathbf{C}\right)\right], \text { no more }}\end{array}$ & Panel thickness \\
\hline Expanded polystyrene & 0,039 & 80 \\
\hline Polyurethane foam & 0,492 & 80 \\
\hline Mineral wool & 0,572 & 80 \\
\hline
\end{tabular}

Table 4. Physical and technical properties and mechanical properties of polyurethane foam

\begin{tabular}{|l|c|}
\hline \multicolumn{1}{|c|}{ Name of indicators } & Norm \\
\hline Density, $\mathrm{kg} / \mathrm{m}^{3}$ no more & 55,0 \\
\hline Thermal conductivity coefficient, $\mathrm{kcal} / \mathrm{mh}^{\circ} \mathrm{C}$, not more & 0,028 \\
\hline $\begin{array}{l}\text { Moisture absorption in 24 hours at a relative air humidity of } 96 \%, \text { vol. } \%, \\
\text { no more }\end{array}$ & 0,11 \\
\hline Water absorption in 24 hours at saturation with water, vol. \%, no more & 2,01 \\
\hline Adhesion strength to metal sheets, $\mathrm{kgf} / \mathrm{cm}^{2}$, not less: & \\
\hline with uniform separation & 3,03 \\
\hline at shift & 2,52 \\
\hline
\end{tabular}




\begin{tabular}{|l|c|}
\hline \multicolumn{1}{|c|}{ Name of indicators } & Norm \\
\hline Tensile strength, $\mathrm{kgf} / \mathrm{cm}^{2}$, not less & 3,0 \\
\hline Shear strength, $\mathrm{kgf} / \mathrm{cm}^{2}$, not less & 2,5 \\
\hline Tensile modulus, $\mathrm{kgf} / \mathrm{cm}^{2}$, no more & 100,0 \\
\hline Shear modulus, $\mathrm{kgf} / \mathrm{cm}^{2}$, no more & 45,0 \\
\hline Content of flame retardant additives, wt. \%, not less & 5,0 \\
\hline
\end{tabular}

Table 5. Physical and technical properties and mechanical properties of expanded polystyrene

\begin{tabular}{|c|c|c|}
\hline \multirow{2}{*}{ Indicator names } & \multicolumn{2}{|c|}{ Panel types } \\
\hline & PD & PT \\
\hline Volume weight, $\mathrm{kg} / \mathrm{m}^{3}$, no more & 120 & 80 \\
\hline $\begin{array}{l}\text { Coefficients of thermal conductivity, } \mathrm{W} /(\mathrm{m} \cdot \mathrm{K}) \\
{\left[\mathrm{kcal} /\left(\mathrm{m} \cdot \mathrm{h} \cdot{ }^{\circ} \mathrm{C}\right)\right], \text { no more }}\end{array}$ & $0,058(0,05)$ & $0,046(0,04)$ \\
\hline Linear technological shrinkage, $\%$, no more & 1,0 & 0,1 \\
\hline Acid number, mg KOH/g, no more & 30 & 30 \\
\hline $\begin{array}{l}\text { Moisture absorption in } 24 \text { hours at a relative air } \\
\text { humidity of } 96 \% \text {, vol. } \% \text {, no more }\end{array}$ & 1,0 & 0,2 \\
\hline $\begin{array}{l}\text { Water absorption in } 24 \text { hours at saturation with water, } \\
\text { vol. } \% \text {, no more }\end{array}$ & 10,0 & 3,0 \\
\hline Strength, $\mathrm{Pa} \cdot 10^{5}\left(\mathrm{kgf} / \mathrm{sm}^{2}\right)$, not less: & & \\
\hline $\begin{array}{l}\text { under tension } \\
\text { under compression } \\
\text { at shift }\end{array}$ & $\begin{array}{c}1,5 \\
1,5 \\
-\end{array}$ & $\begin{array}{c}3,0 \\
- \\
2,0\end{array}$ \\
\hline Elastic modulus, $\mathrm{Pa} \cdot 10^{5}\left(\mathrm{kgf} / \mathrm{sm}^{2}\right)$, no more & 400 & 250 \\
\hline Shear modulus, $\mathrm{Pa} \cdot 10^{5}\left(\mathrm{kgf} / \mathrm{sm}^{2}\right)$, no more & - & 100 \\
\hline $\begin{array}{l}\text { Adhesion strength of metal sheets with insulation, } \mathrm{Pa} \\
\cdot 10^{5}\left(\mathrm{kgf} / \mathrm{sm}^{2}\right) \text {, not less: }\end{array}$ & & \\
\hline $\begin{array}{l}\text { with uniform separation } \\
\text { at shift }\end{array}$ & $\begin{array}{c}1,5 \\
-\end{array}$ & $\begin{array}{l}3,0 \\
2,0\end{array}$ \\
\hline
\end{tabular}

Sandwich panels belong to the class of enclosing structures that are checked and tested for fire resistance without load and tested for fire resistance with a load simulating snow adhesion.

The fire test is carried out in a furnace. The furnace is a series of burners arranged in a certain way, which simulate the fire effect. The temperature regime is set along the curve of conventional types of fire. Be sure to artificially create conditions as close to real as possible during the tests. These conditions are governed by existing international standards. The duration of the tests carried out is determined by the time of loss of panel integrity, the time of loss of bearing capacity and collapse of structures, as well as the time of loss of the heat-insulating component.

Table 6. Physical and technical properties and mechanical properties of expanded polystyrene

\begin{tabular}{|l|c|c|}
\hline \multirow{2}{*}{ Indicator name } & \multicolumn{2}{c|}{$\begin{array}{c}\text { Required values for } \\
\text { mineral wool boards }\end{array}$} \\
\cline { 2 - 3 } & wall, roof & roof \\
\hline 1 Nominal density, $\mathrm{kg} / \mathrm{m}$, not less & 105 & 130 \\
\hline $\begin{array}{l}\text { 2 Standard compressive strength of the core material, } \\
\text { N/mm, not less }\end{array}$ & 0,06 & 0,07 \\
\hline 3 Standard tensile strength (layer rupture) of the core & 0,1 & 0,12 \\
\hline
\end{tabular}




\begin{tabular}{|l|c|c|}
\hline material, N/mm, not less & & \\
\hline $\begin{array}{l}\text { 4 Standard shear strength (shear) of the core material, } \\
\mathrm{N} / \mathrm{mm}, \text { not less }\end{array}$ & 0,06 & 0,067 \\
\hline $\begin{array}{l}\text { 5 Modulus of elasticity of the core material in tension, } \\
\mathrm{N} / \mathrm{mm}\end{array}$ & 5,2 & 5,4 \\
\hline $\begin{array}{l}\text { 6 Modulus of elasticity of the core material in compression, } \\
\mathrm{N} / \mathrm{mm}\end{array}$ & 5,6 & 6,0 \\
\hline 7 Shear modulus of core material, N/mm & 2,5 & 2,6 \\
\hline 8 Thermal conductivity at $(298 \pm 1) \mathrm{K}, \mathrm{W} /(\mathrm{m} \cdot \mathrm{K})$, no more & 0,046 & 0,048 \\
\hline 9 Calculated thermal conductivity, $\mathrm{W} /(\mathrm{m} \cdot \mathrm{K})$, no more & 0,048 & 0,05 \\
\hline 10 Moisture, $\%$ by mass, no more & 1,0 & 1,0 \\
\hline 11 Content of organic substances, $\%$ by mass, no more & 4,5 & 4,5 \\
\hline
\end{tabular}

During the tests, the SIP panels showed high strength and quality characteristics, significantly exceeding those established by the technical conditions:

The panel is $224 \mathrm{~mm}$ thick (PSBS-25 density is $21 \mathrm{~kg} / \mathrm{m}^{3}$, Austrian OSB-3 plate by Egger is $12 \mathrm{~mm}$ ) Withstands a uniformly distributed load of $660 \mathrm{~kg} / \mathrm{m}^{2}$. The breaking load is 2000 $\mathrm{kg} / \mathrm{m}^{2}$.

The panel is $174 \mathrm{~mm}$ thick (PSBS-25 density is $21 \mathrm{~kg} / \mathrm{m}^{3}$, Austrian OSB-3 board by Egger is $12 \mathrm{~mm}$.) Withstands a uniformly distributed load of $540 \mathrm{~kg} / \mathrm{m}^{2}$. The breaking load is $1480 \mathrm{~kg} / \mathrm{m}^{2}$.

The adhesion strength of the components of structural insulating panels is $0.14 \mathrm{MPa}=141$ $\mathrm{kg} / 100 \mathrm{~cm}^{2}$.

Modern modular buildings from sandwich panels are manufactured at the factory, after which they only have to be delivered and assembled. This factor allows you to carry out construction in the shortest possible time, as well as significantly save on finishing the house. The last factor is due to the fact that sandwich panels have a surface that does not require additional processing - putty or plaster, and are produced already painted in the color chosen by the customer.

Sandwich panels are used in the construction of both residential and industrial buildings. The unique design and low weight of products such as sandwich panels are their main advantages, which entail a large margin of safety and low costs for transportation, loading and installation.

In addition, the low weight of the sandwich panels reduces the load on the foundation, which means that the cost of geological research of the soil is reduced, which in general also affects the cost of construction.

\section{Conclusion}

Based on the results of the studies performed, the following conclusions can be drawn:

1) On the basis of experimental studies were determined the physical and mechanical characteristics of the polyurethane foam filler of the middle layer: density $55 \mathrm{~kg} / \mathrm{m}^{3}$, thermal conductivity coefficient $0.028 \mathrm{kcal} / \mathrm{m} \cdot \mathrm{h}$, moisture absorption $0.1 \%$ in 24 hours at a relative humidity of $96 \%$, water absorption $2.0 \%$ in 24 hours at saturation with water, adhesion strength to metal sheets at uniform tearing off $3.0 \mathrm{kgf} / \mathrm{cm}^{2}$, and at shear 2.5 $\mathrm{kgf} / \mathrm{cm}^{2}$, tensile strength $3.0 \mathrm{kgf} / \mathrm{cm}^{2}$, shear strength $2.5 \mathrm{kgf} / \mathrm{cm}^{2}$, modulus of elasticity in tension $100 \mathrm{kgf} / \mathrm{cm}^{2}$, shear modulus $45 \mathrm{kgf} / \mathrm{cm}^{2}$, content of flame-extinguishing additives, weight of $5 \%$ of the material of sheathing and fragments of the roofing panel when working in tension, compression and shear. The studies carried out allow us to assert that the insulation has pronounced orthotropic properties. 
2) Full-scale tests made it possible to determine the nature of the behavior of roofing panels when exposed to one-time and cyclic loads. Also, the features of the distribution of stresses and strains were established during linear and nonlinear work. In addition, the ultimate breaking loads and the specific features of the destruction of panels in one-span and twospan schemes were identified and established.

3) According to the results of experiments, it was found that in terms of thermal technical characteristics, sandwich panels are significantly superior to traditional materials.

4) A comparative economic calculation of costs has been carried out. It is economically profitable to buy such components as polyol and isocyanate (for spraying and pouring polyurethane foam) in China, since the prices of European countries are much higher. When buying components in a wholesale weight of $100 \mathrm{~kg}$, the savings are 22.284 tenge. Thus, taking into account all the advantages of such products as sandwich panels, the economic feasibility of using prefabricated buildings, the construction of prefabricated buildings is becoming the most popular and affordable, and the breadth of use of sandwich panels is unlimited.

\section{References}

1. U. Ilyin, Yu. Skujans, G. Andersons, J. Kreilis. Guidelines for the design and construction of sandwich panels (Latvian University of Agriculture, 2005)

2. Russian architectural and construction encyclopedia, 5 volumes (Moscow, 2004, 2005, 2006)

3. V.M. Vasiliev, Y.P. Panibratov, S.D. Reznik, V.A. Khitrov. Management in construction (Moscow, 2004)

4. T.N. Tsai, P.G. Grabovoy, V.A. Balshakov. Organization of construction production. (ASV. 2004)

5. Yu.D. Amirov Product qualimetry and certification. (Moscow, 2004)

6. GOST 15.901-91. System of product development and launching it into manufacture. Building components, products and materials.

7. Law of the Republic of Kazakhstan "On standardization and certification" dated 18.01.93.

8. ST RK 1.0-93 State system of standardization of the Republic of Kazakhstan. Basic provisions

9. ST RK 1.4-93 State system of standardization of the Republic of Kazakhstan. Enterprise standards. General provisions

10. ST RK 1.5-93 State system of standardization of the Republic of Kazakhstan. General requirements for the construction, presentation, design and content of standards

11. GOST 32603-2012 Three-layered metal panels with mineral wool insulation. Specifications.

12. GOST 31913-2011 (EN ISO 9229: 2007) Thermal insulating materials and products. Terms and definitions

13. GOST 9573-96 Thermal insulating plates of mineral wool on synthetic binder. Specifications

14. GOST 23486-79 Three-layer metal wall panels with polyurethane foam insulation. Technical conditions.

15. GOST 21562-76 Metal-faced building panels with foam plastic thermal insulation. General specifications.

16. GOST 32310-2012 (EN 13164: 2008) Factory made termal insulation products of extruded polystyrene foam (XPS) for building. Specifications. 